Kanat, Ö. (2020). Eğitim fakültelerindeki çocuk edebiyatı dersinin öğretmen adaylarının görüşlerine göre değerlendirilmesi. Ana Dili Eğitimi Dergisi, 8(3), 646-656.

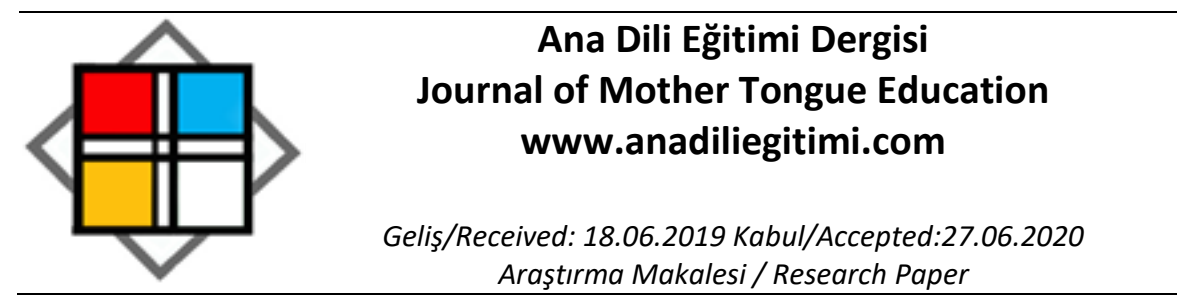

\title{
Eğitim Fakültelerindeki Çocuk Edebiyatı Dersinin Öğretmen Adaylarının Görüşlerine Göre Değerlendirilmesi ${ }^{* * *}$
}

\author{
Özlem KANAT $T^{* * *}$
}

\begin{abstract}
Öz
Bu çalışmanın amacı öğretmen adaylarının çocuk edebiyatı dersine ilişkin görüşlerini saptamaktır. Bu amaçla ülkemizdeki eğitim fakültelerinde (yedi coğrafi bölgeden toplam 14 üniversite) öğrenim gören ve çocuk edebiyatı dersini almış olan 1431 öğretmen adayının bu derse ilişkin görüşleri alınmıştır. Veriler; araştırmacının geliştirdiği, dörtlü Likert tipi maddelerden ve açık uçlu sorulardan oluşan sormacayla toplanmıştır. Sormacanın Likert tipi maddeleriyle toplanan verilerin sıklık değerleri belirlenmiş, açık uçlu soruların yanıtlardan elde edilen verilere ise betimsel kodlama işlemi uygulanmıştır. Betimsel kodlama sonucunda "çocuk edebiyatı dersine ilişkin değiştirilmek istenenler", "çocuk edebiyatı dersine ilişkin öneriler" ve "çocuk edebiyatı dersi kapsamında nitelikli bulunan çocuk edebiyatı yapıtları" temalarına ulaşılmıştır. Bu bağlamda öğretmen adayları, çocuk edebiyatı dersinin içeriğine ilişkin eleştirilerini; eğitim durumlarına dönük beklentilerini ve mevcut durumdan memnuniyetsizliklerini dile getirmişlerdir. Öğretmen adaylarının görüşlerine göre temel sorunlar arasında güncel çocuk edebiyatı yapıtlarını yeterince tanımamaları da bulunmaktadır. Bunun yanında ders saatlerinin yetersizliği, derste kullanılan öğretim yöntem ve tekniklerinden kaynaklanan sorunlar, öğretmen adaylarının nitelikli kitapları tanımadaki yetersizliği elde edilen sonuçlar arasında yer almaktadır.
\end{abstract}

Anahtar Kelimeler: Çocuk edebiyatı, çocuk edebiyatı öğretimi, öğretmen adayları, eğitim programı.

\section{Evaluation of Children's Literature Course in the Faculties of Education According to Preservice Teachers' Opinions}

\begin{abstract}
This study evaluate the status of children's literature course based on the opinions of preservice teachers. For this purpose, preservice teachers studying at education faculties in Turkey (1431 participants) expectations regarding data related to children's literature course and suggestions were collected with four Likert type data collection tool and open-ended questions. The data collected with the Likert type part of the questionnaire were evaluated as percentage and frequency, and as a result of the descriptive coding process of open-ended questions, the themes of "those who want to be changed regarding the children's literature course", "suggestions about the children's literature course" and "children's literature works qualified within the scope of the children's literature course" were reached. In this context, the preservice teachers stated their criticisms about the content of the children's literature course, they expressed their expectations regarding learning experience and dissatisfaction with the current situation. Accordingly, the preservices teachers expressed their expectations for changing the course content in particular and learning experience as to children's literature course as well as dissatisfaction due to existing situation. According to the preservice teachers, one of the major problems is that they do not have
\end{abstract}

\footnotetext{
${ }^{*}$ Bu makale araştırmacının "Eğitim Fakültelerindeki Çocuk Edebiyatı Öğretiminin Değerlendirilmesi (Bir Ders Tasarımı Örneği)" adlı doktora tezinden üretilmiştir.

** Araştırmanın etik kurulu izni: Ankara Üniversitesi Etik Kurulu, 06/06/2016, 180.

*** Dr., Ankara Üniversitesi, Eğitim Bilimleri Fakültesi, Güzel Sanatlar Eğitimi Bölümü, Ankara, ozlemktkanat@gmail.com, ORCID: orcid.org/0000-0002-9071-2700
} 
sufficient knowledge of actual children literature works. In addition, the inadequacy of the course hours, the problems arising from the teaching methods and techniques used in the course, the inadequacy of the preservices teachers in recognizing qualified books are among the results obtained. According to the opinions of the preservices teachers, the main problems include not being adequately introduced to the current children's literature works. In addition, the inadequacy of the course hours, the problems arising from the teaching methods and techniques used in the course, the inadequacy of the preservices teachers in recognizing qualified books are among the results obtained.

Keywords: Children's literature, children's literature education, preservice teachers, curriculum.

\section{Giriş}

Bireyin okuma kültürü edinme süreci eğitim-öğretim yaşamının niteliğini etkileyen değişkenler arasında yer alır. Çocuğun okuma kültürü edinme sürecindeki birincil kaynaklar ise çocuk edebiyatı yapıtlarıdır (Sever, 2010). Çocuk edebiyatı yapıtları çocukları bilişsel, duyuşsal ve devinişsel anlamda etkileyebilen nitelikli metinlerdir (Aslan, 2007, Dilidüzgün, 2004a; Kantemir, 1979; Nas, 2014; Neydim, 2006; Sever, 2010). Çocuk edebiyatı metinlerinin eğitimde kullanılması, eğitim-öğretim sürecini olumlu yönde etkiler (Aslan, 2006; Russel, 2009; Sever, 2011; Sever, 2007; Sever, Kaya ve Aslan, 2006). Bu nedenle okulöncesi dönemden başlayarak eğitimin birçok aşamasında çocuklara seslenen nitelikli metinlerden yararlanılması gerekir (Backer, 2003; Baş, 2015; Dilidüzgün, 2004; Sever, 2010; Şirin, 2000; Yalçın ve Aytaş, 2016).

Çocuk edebiyatı metinleri eğitim-öğretim etkinlikleri için nitelikli materyallerdir; anadili dersleri dışında başka derslerde de kullanılabilir (Büyükkavas, Kuran ve Ersözlü, 2009). Matematikten fen bilgisine; sosyal bilgilerden felsefeye değin birçok derste çocuk edebiyatı yapıtlarından yararlanılmaktadır (Campbell, 2014; Rief ve Heimburge, 2006; Shavit, 1986: ix; Slavin, 2014, Wartenberg, 2009). Yabancı dil öğretiminde de yazınsal metinler kullanılmaktadır (Erişek ve Yücel, 2002; Kudat, 1996).

Öğretmenler için çocuk edebiyatı yapıtlarından yararlanmanın birçok yolu vardır (Rudman, 1995). Öğretmenlerin çocuk edebiyatı yapıtlarından yararlanma konusunda çeşitli olanaklarının olduğunu bilmesi ve kendi gereksinimleri doğrultusunda yeni kullanım yolları geliştirebilmesi önemlidir. Bu bağlamda derslerde öğretmen adaylarının farklı metinleri nasıl okuyacakları, okuduklarını anlamaları için nasıl bir yol izleyecekleri konusunda bilinçlendirilmeleri gerekir (Dilidüzgün, 2004a).

\section{Öğretmen Yetiştirme Programlarında Çocuk Edebiyatı Dersi}

Ülkemizde çocuk edebiyatının tarihi Tanzimat'a dayanır (Çıkla, 2005). Çocuk edebiyatı bir ders olarak ancak ilk kez 1953'te Köy Enstitülerinin eğitim programında yer alır (Demircan, 2007). Köy Enstitüleri eğitim programına göre çocuk edebiyatı dersi, öğretmen adayının çocuklara seslenen kitap ve dergileri tanımasına ve değerlendirebilmesine; ayrıca tekerleme, masal örneklerini bilmesine olanak sağlayacak biçimde yapılandırılmıştır (MEB, 1953). Buna karşın çocuk edebiyatının eğitim fakültelerindeki öğretmen yetiştiren programlarda bir ders olarak yer alması 1998'de gerçekleşir (Sever, 2013). 1999'dan itibaren eğitim fakültelerinde okutulan çocuk edebiyatı dersinin, konumunda 2006-2007 yapılanmasıyla büyük bir değişikliğe gidilmiştir (Sever, 2013). Eğitim fakülteleri programlarının yeniden yapılandııılması sonrası çocuk edebiyatı dersinin eğitim fakültelerindeki ulusal kredisi ve süresi değiştirilmiş; bu değişiklik uyarınca eğitim fakültelerinin yalnızca okul öncesi, sınıf ve Türkçe öğretmenliği programlarında bir yarıyıl okutulan 3 kredilik bir ders (zorunlu) olarak tanımlanmıştır (YÖK, 2007). Öte yandan 2018'de bir başka eğitim fakülteleri programlarında yeniden yapılanmaya gidilmiştir. Anılan yeniden yapılanmayla çocuk edebiyatı dersi, amaç, içerik, süre ve yer aldığı programlardaki ağırlığı bağlamında değiştirilmiştir (YÖK, 2018). Çocuk edebiyatı dersi Türkçe öğretmenliği programı için iki kredilik alan eğitimi dersine (zorunlu) dönüştürülmüş dersin içeriği şu şekilde düzenlenmiştir:

"Dünyada ve Türkiye'de çocuk edebiyatı tarihi, çocuk edebiyatı ve okuma alışkanlığı/kültürü; çocuk edebiyatı ürünlerinin taşıması gereken nitelikler (tasarım, içerik 
ve eğitsel); yazınsal çocuk edebiyatı türleri (şiir, öykü, roman vb.), bilgilendirici-öğretici çocuk edebiyatı türleri; çocuk klasikleri; çocuklara seslenen diğer yazınsal türler (destan, masal, efsane) ve dilsel gereçlerin (sayışmaca, tekerleme, bilmece vb.) çocukların gelişimlerine katkıları; çocuk edebiyatı ürünlerinin yaş gruplarına göre seviyelendirilmesi; görsel medya ve çocuk (çocuklar için çizgi film/çizgi sinema/animasyon); çocuk edebiyat ürünleri üzerine incelemeler." (YÖK, 2018).

Aynı düzenlemeyle çocuk edebiyatı dersi ilkokul öğretmenliği programında 2 kredilik alan eğitimi seçimlik ders olarak konumlandırılmış ve dersin içeriği şu şekilde düzenlenmiştir:

“Dünyada ve Türkiye' de çocuk edebiyatının gelişimi; çocukluk evresinde, nitelikli çocuk kitaplarıyla tanışmanın önemi ve okuma kültürü edinmiş düşünen, duyarlı bireylerin yetiştirilmesinde çocuk edebiyatı yapıtlarının işlevi; çocuk edebiyatı yapıtlarında bulunması gereken özelliklerin (tasarım, içerik ve eğitsel) örneklerle incelenmesi; niteliksiz çocuk kitaplarının örneklerle gösterilmesi ve bunların çocukların gelişim özellikleri üzerindeki olumsuz etkilerinin tartışıması; öğretmen adaylarının, okuduğu-incelediğ kitapların yaş gruplarına göre çocuklara uygunluğunun ve bunların çocukların hangi gelişimlerine katkı sağlayacağının belirlenmesine yönelik çalışmalar; çocuklara seslenen çeşitli yazınsal türlerin (destan, masal, şiir, öykü, roman, vb.) ve dilsel gereçlerin (sayışmaca, tekerleme, bilmece vb.) çocukların gelişimlerine olan katkılarının belirlenmesi." (YÖK, 2018).

Okul öncesi öğretmenliği programında ise çocuk edebiyatı dersinin adı "erken çocukluk dönemi edebiyatı" olarak değiştirilmiş; ilgili ders, alan eğitimi dersi (zorunlu) olarak tanımlanmış, ilkokul öğretmenliği programıyla aynı çerçeve içerik kullanılmıştır. Üç programdaki çocuk edebiyatı dersinin yeni ve eski içeriğinde öğretmen adaylarının nitelikli çocuk kitaplarını seçebilmeleri önemli bir yer tutmaktadır.

Öğretmen adaylarının çocuklara okuma alışkanlığı kazandırılması konusunda duyarlı olduğu söylenebilir (Kurudayıoğlu ve Çelik, 2013). Buna karşın birçok çalışmada öğretmenlerin/öğretmen adaylarının nitelikli çocuk kitaplarını nasıl seçeceklerini bilmedikleri; çocuk edebiyatı yapıtlarını tanımadıkları görülmüştür (Celepoğlu ve Çetindağ, 2012; Maltepe, 2009; Sever, 2013; Yazıcı-Okuyan, 2009). Bu durum çocuk edebiyatı dersine ve öğretimine ilişkin birçok sorunun varlığını gösterir. Sorunun tanımlanması için çocuk edebiyatı dersinin birçok değişkeniyle ele alınması gerekir. Eğitim programı, program ile hedef (amaç), içerik, öğrenme-öğretme süreci ( eğitim durumu) ve değerlendirme ögeleri (ölçme-değerlendirme) arasındaki devingen ilişkiler bütünü olarak tanımlanmaktadır (Demirel, 2015). Herhangi bir ders yapılandırılırken eğitim programın dört temel öğesi temel alınır (Demirel, 2015). Anılan dört temel öğe, amaç, içerik, eğitim durumları ve ölçmedeğerlendirmedir (Demirel, 2015). Bu nedenle bu çalışmada da programın temel değişkenlerine odaklanılarak "Ülkemizdeki eğitim fakültelerinde çocuk edebiyatı dersinin durumu programın dört öğesi (dersin amaçları, içeriği, eğitim durumları ve ölçme-değerlendirme) bağlamında öğretmen adaylarının görüşlerine göre nasıl değerlendirilebilir?" sorusuna yanıt oluşturmaya çalışılmıştır.

\section{Araştırmanın Modeli}

\section{Yöntem}

Bu çalışmada, araştırmanın problemini daha derinlemesine incelemek amacıyla "temel nitel araştırma deseni" tercih edilmiştir. Temel nitel araştırmalar, en yaygın nitel araştırma deseni olarak değerlendirilmekte ve eğitim başta olmak üzere yönetim, sağlık, danışma gibi çeşitli alanlarda sıklıkla kullanılmaktadır (Merriam, 2009). Temel nitel araştırma deseninin seçilmesinde bir başka etken ise çalışmanın hem nitel hem de nicel veriler içermesidir. Bir başka nedense temel nitel araştırma deseninin sağladığı olanaklarla araştırmacıya ele alınan konuda derinlemesine çözümleme yapma olanağı tanımasıdır (Creswell ve Plano Clark, 2015).

\section{Örneklem / Araştırma grubu}

Bu araştırmanın çalışma grubunu ülkemizdeki üniversitelerin eğitim fakültelerinde, okul öncesi öğretmenliği, sınıf öğretmenliği ile Türkçe öğretmenliği programlarında öğrenim görmekte olan, çocuk 
edebiyatı dersini almış ve çalışmaya katılmaya gönüllü olan öğretmen adayları ( $n=1431$ ) oluşturmaktadır. Çalışma grubu, amaçlı örnekleme türlerinden "maksimum çeşitlilik" örnekleme yöntemiyle belirlenmiştir. Öğretmen adaylarının çocuk ve gençlik edebiyatı dersinin eğitim fakültelerindeki durumuna ilişkin görüşlerini maksimum çeşitlilik bağlamında saptayabilmek amacıyla çalışma grubu; farklı coğrafi bölgelerdeki (Ege, Marmara, iç̧ Anadolu, Akdeniz, Karadeniz, Doğu Anadolu, Güneydoğu Anadolu) üniversiteler, farklı bölümler (okul öncesi öğretmenliği, sınıf öğretmenliği, Türkçe öğretmenliği), öğrenci ve öğretim elemanı sayısı bağlamında farklı büyüklükteki üniversiteler (öğrenci sayısı 50.000 ve üzerinde olanlar; öğrenci sayısı 50.000'in altında olanlar) gibi değişkenler göz önünde bulundurularak oluşturulmuştur. Çalışma grubunda yer alan öğretmen adaylarına ilişkin bilgiler Tablo 1 ve 2'de sunulmuştur:

Tablo 1.

Öğretmen Adayı Çalışma Grubuna ilişskin Bilgiler

\begin{tabular}{lll}
\hline Cinsiyet & $f$ & $\%$ \\
\hline Erkek & 365 & 25.5 \\
Kadın & 1066 & 74.5 \\
\hline Toplam & 1431 & 100 \\
\hline
\end{tabular}

Tablo 1'de görüldüğü üzere, araştırma kapsamında eğitim fakültelerinin farklı programlarında öğrenim gören ve çocuk edebiyatı dersini almış 1431 öğretmen adayına ulaşılmışırı. Çalışma grubundaki öğretmen adaylarının \%74.5'i kadın, \% 25.5'i ise erkektir. Araştırmanın veri toplama aşamasında çalışma grubuna dâhil edilecek öğretmen adaylarının cinsiyet dağılımı dengesinin sağlanması amaçlanmış olmasına karşın çalışmaya katılmaya gönüllü öğretmen adaylarının dâhil edilmesi durumu öncelenmiştir.

Tablo 2'de çalışma grubunda yer alan öğretmen adaylarının devam ettikleri lisans programlarına ilişkin bilgiler paylaşılmıştır.

Tablo 2.

Öğretmen Adaylarının "Çocuk Edebiyatı" Dersini Aldıkları Lisans Programları

\begin{tabular}{lll}
\hline Öğretmen Eğitimi Lisans Programı & $f$ & $\%$ \\
\hline Okul Öncesi Öğretmenliği & 247 & 17.3 \\
Sını Öğretmenliği & 491 & 34.5 \\
Türkçe Öğretmenliği & 645 & 45.3 \\
Üstün Zekâlılar Öğretmenliği & 34 & 2.4 \\
Diğer (Sosyal Bilimler, Illköğretim) & 7 & 0.5 \\
Belirtilmemiş & 7 & \\
\hline Toplam & 1431 & 100 \\
\hline
\end{tabular}

Tablo 2'ye göre, çalışma grubundaki öğretmen adaylarının çoğu sırayla; Türkçe öğretmenliği, sınıf öğretmenliği ve okul öncesi öğretmenliği programlarına devam etmektedir.

\section{Veri Toplama Araçları}

Sormaca, eğitim programlarının temel öğeleri olan amaçları, içeriği, eğitim durumları ve ölçmedeğerlendirme süreçlerine (Demirel, 2017; Gürkan, 2000) göre yapılandırılmıştır. Bu bağlamda çocuk edebiyatı dersini alan öğretmen adayları için "Öğretmen Adaylarının Çocuk Edebiyatı Dersine ílişkin Görüşlerini Belirleme Sormacası" geliştirilmiştir. Sormacaların geliştirilmesi aşamasında ilk olarak, alanyazın taraması doğrultusunda madde havuzu oluşturulmuş, daha sonra taslak olarak hazırlanan sormacalar Türkçe eğitimi (4), eğitim programları ve öğretim (2), ölçme ve değerlendirme (2) alanlarında 8 kişiden oluşan uzman ekibin görüşleri doğrultusunda düzenlenmiştir. Pilot çalışma için sormaca, çalışma grubunda yer almayan öğretmen adaylarına uygulanmış; bu doğrultuda işlemeyen maddelerde gerekli düzenlemeler yapılarak sormacaya son biçimi verilmiştir. 


\section{İşlem / Verilerin Toplanması}

Veriler, 2015-2016 eğitim-öğretim yılı bahar yarıyılının sonunda eğitim fakültelerinden toplanmıştır. Öğretmen adaylarından; çocuk edebiyatı dersinin amaçları, içeriği, eğitim durumları ve ölçme-değerlendirme süreçlerine ilişkin maddeler içeren sormacanın sorularına yanıt vermeleri istenmiştir.

\section{Verilerin Analizi}

Temel nitel araştırmalarda bulgulara dayalı olarak yapılan çözümleme ve yorumlar, araştırmacının, katılımcıların incelenen olguyu ya da süreçleri anlamlandırmalarına yönelik belirlemelerini içerir (Merriam, 2009). Bu amaçla şu basamaklar izlenmiştir:

\section{Geçerlik ve Güvenirlik}

Çalışmanın geçerlik ve güvenirliğini sağlamak amacıyla akran bilgilendirmesi, denetleme kayıtları, uzman görüşüne başvurma ve pilot deneme yöntemleri kullanılmıştır. Bu yöntemler, Lincoln ve Guba'nın (2013) nitel araştırmalarda sıklıkla kullanılan geçerlik ve güvenirlik stratejilerinden inanılabilirlik ve onaylanabilirlik boyutları bağlamında açıklanmış; çalışmanın geçerlik ve güvenirlik boyutları sağlanmıştır.

Akran bilgilendirmesi: Çalışmanın veri toplama aşamasından sonuna değil nitel araştırma alanında deneyimli iki uzman araştırmacının çalışmaya ilişkin görüşleri alınmıştır. Anılan iki araştırmacı, veri toplama araçlarının geliştirilmesi, uygulanması ve değerlendirilmesi sürecinde uzman görüşü sunarak çalışmanın en iyi şekilde yürütülmesi için araştırmacıya destek olmuştur. Bu süreç, araştırmacının yürütmekte olduğu araştırmayla ilgili daha derinlemesine düşünmesini; araştırma sürecinde yaşanan sıkıntılar olduğunda araştırmacıya görüş ve önerilerle yol gösterilmesini sağlamıştır. Alanyazında akran bilgilendirmesi olarak adlandırılan bu süreç, çalışmanın inanılabilirlik boyutuna da katkı sağlamıştır.

Denetleme kayıtları: Araştırmanın veri toplama ve veri analizi süreçlerinde ne tür işlemler yapıldığı ve bu işlemlerin sırasına ilişkin bilgiler kayıt altına alınmıştır. Denetleme kayıtlarının açıkça belirtilmesi, araştırmanın onaylanabilirliği açısından önemli bir aşama olarak değerlendirilmektedir.

Uzman görüşüne başvurma ve pilot deneme: Sormaca, 8 kişiden oluşan uzman ekibin görüşüne sunulmuştur. Uzmanların görüş ve önerileri doğrultusunda düzenlenerek maddelerin anlaşılabilirliğini ve ölçme tekniği açısından uygunluğunu değerlendirmek üzere dahil olmayacak öğretmen adaylarına uygulanmıştır. Bu şekilde gerçekleştirilen pilot deneme, ölçme araçlarının geçerliğinin sağlanması amacıyla yapılmıştır. Sınıf öğretmenliği bölümünden 50 öğretmen adayına ve okul öncesi öğretmenliği bölümünden 30 öğretmen adayına 2015-2016 Eğitim Öğretim yılı bahar yarıyılının Nisan ayında pilot uygulama yapılmıştır. Uygulama sonrasında öğretmen adayları tarafından yeterince anlaşılmadığı düşünülen maddeler, daha açık ve anlaşılır biçimde yazılmış ve sormacanın son hali tekrar uzman görüşüne sunulduktan sonra veri toplama aracı olarak kullanılmıştır.

\section{Etik Kurulu İzni}

Veri toplama araçları Ankara Üniversitesi Etik Kurula sunulmuş; aşağıda bilgileri sunulan karar ile çalışmanın araştırma ve yayın etiğine uygun olduğu belirtilmiştir:

Kurul adı = Ankara Üniversitesi Etik Kurulu

Karar tarihi $=06 / 06 / 2016$

Belge sayı numarası $=180$

\section{Bulgular, Tartışma ve Sonuç}

Çalışmanın amaçları doğrultusunda elde edilen veriler çözümlendiğinde dersin amaçları, içeriği, eğitim durumu ve ölçme-değerlendirme açısından aşağıdaki bulgulara ulaşıımıştır:

\section{Öğretmen Adaylarının Dersin Amaçları Bağlamındaki Görüşleri Nelerdir?}

Araştırmaya katılan öğretmen adaylarının yaklaşık \%60'ının dersin çerçeve amaçları olan "çocuk edebiyatı yapıtlarının tasarım ve içerik tanıtılması; okuma kültürünün ve çocuğun dilsel gelişim 
süreçlerinin kavratılması" bağlamında derste yürütülen süreçleri yeterli buldukları görülmüştür. Maltepe (2009)'nin gerçekleştirdiği çalışmada öğretmen adaylarının çocuğa göre kitap seçiminde zorlandıkları görülmüştür. Öte yandan İnce Samur (2018)'un çalışmasında öğretmen adayları "çocuğa göre" ve "nitelikli" kitap seçebilmeyi dersin önemli amaçları olarak tanımlamışlardır. Yılmaz (2016)'ın çalışmasında Türkçe öğretmen adayları, çocuk edebiyatı dersinde edindiklerinin çocuklara uygun kitapları seçmelerine katkıda bulunacağını belirtmişlerdir. Bu bağlamda İnce Samur'un ve Yıımaz'ın çalışmasının bulgularıyla bu çalışmanın bulguları örtüşmektedir. Buna karşın öğretmen adaylarııın \%44.2'si dersin amaçları arasında yer alan okuma kültürü edindirme kavramının yeterince açıklanmadığını; bu kavrama daha çok yer verilmesi gerektiğini düşünmektedir.

\section{Öğretmen Adaylarının Dersin İçeriği Bağlamında Görüşleri Nelerdir?}

Öğretmen adaylarının \%59.3'ü çocuk edebiyatı alanına ilişkin kuramsal bilgilere derste yeterince yer verildiğini düşünmektedir. "Çocuklara seslenen yazınsal metinlerin özelliklerinin yeterince anlatılmadığını düşünüyorum." maddesine ise öğretmen adaylarııın \% 47.6'sı katılmamaktadır.

Öğretmen adaylarının \%57.9'unun "Dünya çocuk edebiyatına ilişkin temel bilgilere yeterince yer verildiğini düşünüyorum." maddesine olumlu yanıt verdiği görülmüştür. Adayların \%54.6'sı, "Çocuk edebiyatının ülkemizdeki gelişimine ilişkin ayrıntılı bilgi verildiğini düşünüyorum." maddesine olumlu; \% 45.4'ü ise olumsuz yanıt vermiştir. Bu oranlara bakıldığında öğretmen adaylarııın çocuk edebiyatı dersinde, dünya çocuk edebiyatına ilişkin temel bilgilere daha fazla yer verildiğini düşündükleri görülmektedir. Adayların \%54.8'i çocuklar için yazılmış öğretici-bilgilendirici metinlerin özelliklerinin yeterince anlatılmadığını düşünmektedirler. Oysa bu metinler, çocuk edebiyatı yapıtlarının yanı sıra eğitimde sıklıkla yararlanılan kaynaklardır. Öğretici metinler, öğretmen adaylarının belli bir konuda bir kavramı, olguyu ya da kavramlar/olgular bütününü öğreten, yazınsallık boyutu olmayan, öğretme işlevine odaklanmış metinlerdir (Güneş, 2013). Bu bağlamda öğretmen adaylarına bu kitapların özellikleri ve eğitim süreçlerinde nasıl yararlanılabileceğine ilişkin bilgi sunulması beklenir. Ayrıca dersin içeriğinde çocukların yaş gruplarına göre dilsel gelişim özelliklerine yeterince yer verildiği (\%58.3) de elde edilen bulgular arasındadır. Kolaç, Demir ve Karadağ (2012)'ın çalışmasında öğretmen adaylarının çocukların dilsel beceri düzeylerine dönük bilgi sahibi oldukları sonucuna ulaşılmıştır. Bu bağlamdan anılan sonuçlar, bu çalışmanın bulguları uyumludur.

\section{Öğretmen Adaylarının Dersin Eğitim Durumları Bağlamında Görüşleri Nelerdir?}

Öğretmen adaylarının yaklaşık \%60'ı, çocuk edebiyatı yapıtlarının nasıl inceleneceğinin örneklerle yeterince açıklandığını düşünmektedir. Öğretmen adaylarının yaklaşık \%40’ı ise bu görüşe katılmamakta; \%53'ü, çocuk edebiyatı dersinde yeterince telif ya da çeviri çocuk kitabı örneği gösterilmediğini düşünmektedir. Yapılan birçok çalışmada ortaya çıkan sonuçlara göre öğretmen adayları, çocuk edebiyatı dersinde örnek uygulamaların yetersiz olduğunu düşünmekte ve dersin uygulamaya dayalı yürütülmesini beklemektedir (Bağcl, 2007; Kan, 2011; Uçgun, 2010; Ulutaş ve Kıymaz, 2012, Yazıcı Okuyan, 2009). Bu bulgular, çalışmanın sonuçlarıyla örtüşmektedir. Öte yandan bu bulguları destekleyen başka sonuçlar da elde edilmiştir. Örneğin, öğretmen adaylarının yarısından çoğunun (\%53.5) çocuk edebiyatı yapıtlarını sınıf ortamında nasıl kullanacağını bilmedikleri görülmektedir. Öğretmen adayları, çoğunlukla çocuk edebiyatı yapıtlarını eğitim uygulamalarında kullanma konusunda yeterli bilgi ve beceriyi kazanamadıklarını dile getirmiştir. Öğretmen adaylarının çok çeşitli çocuk edebiyatı yapıtlarıyla buluşturulması beklenmektedir. Bu yapıtların sınıf ortamında nasıl kullanılacağını örnekleyen ders içi uygulamalar konusunda dersin eğitim durumu yeterli bulunmamıştır. Çalışmada elde edilen bir başka bulgu ise çocuk edebiyatı dersinin süresinin yetersiz olduğudur. Çalışmaya katılan öğretmen adaylarının \%47.8'i ders süresinin yeterli olmadığını ifade etmişlerdir. Yılmaz (2016)'ın çalışmasının sonuçları ile benzerlik taşımaktadır. Yılmaz (2016)'ın çalışmasına katılan öğretmen adayları da çocuk edebiyatı dersinin süresinin yetersiz olduğu belirtmişlerdir. Öğretmen adaylarının bu konuya ilişkin beklentileri arasında dersin süresinin artırılması, dersin bir dönemden çok okutulması da yer almaktadır. 
Öğretmen adaylarının \%54'ü çocuk edebiyatı dersinde alandaki bilimsel çalışmalarla buluşturulduğunu belirtmiştir. Buna karşın öğretmen adaylarının yaklaşık \%46'sının bu yargıya katılmadıkları görülmüştür. Öğretmen adaylarının yaklaşık \%60'ı çocuk edebiyatı dersinin genel kültürlerine önemli katkısının olmadığını; buna karşın yaklaşık \%70'i dersin öğretmenlik alan bilgisine katkısı olduğunu ifade etmiştir.

Öğretmen adaylarının \%46.8'i ders yönergesinin içeriğinin yeterli olmadığını belirtmiştir. Buna karşın çocuk edebiyatı dersinin yönergesinin öğretmen adaylarının \%53,2'si tarafından ise yeterli bulunduğu anlaşılmaktadır.

Çalışmaya katılan öğretmen adaylarından ders kapsamında buluştukları çocuk kitaplarından nitelikli buldukları üç ya da daha fazla kitabın adını yazmaları istenmiştir. 1431 katılımcının 1023'ü (\%71.5) en az bir kitap adı anımsarken; iki veya daha fazla kitap adı yazan öğretmen adayı sayısı 896 (\%62.6)'da kalmıştır. Üç ve daha fazla sayıda kitap adı yazın öğretmen adaylarının sayısı ise 730 (\%51) olarak tespit edilmiştir. Toplamda 1431 öğretmen adayı 2882 kitap önermiştir. Aşağıdaki tabloda öğretmen adaylarınca 10'dan daha çok tekrarlanan kitapların dağılımı gösterilmiştir ${ }^{1}$ :

Tablo 3.

Öğretmen Adaylarının Ders Kapsamında Buluştukları ve Nitelikli Buldukları Çocuk Kitapları

\begin{tabular}{lcclcc}
\hline \multicolumn{1}{c}{ Kitap } & $f$ & $\%$ & & Kitap & \% \\
\hline Küçük Prens & 354 & 12.28 & Ökkeş Dizisi & 21 & 0.73 \\
Şeker Portakalı & 133 & 4.61 & Benim Minik Kırmızı Balığım & 19 & 0.66 \\
Vanilya Kokulu Mektuplar & 65 & 2.26 & Alice Harikalar Diyarında & 18 & 0.62 \\
Küçük Karabalık & 105 & 3.65 & Charlie'nin Çikolata Fabrikası & 32 & 1.11 \\
Uyurgezer Fil & 54 & 1.87 & Çavdar Tarlasında Çocuklar & 17 & 0.59 \\
Fadiş & 49 & 1.70 & Ece ile Yüce & 16 & 0.56 \\
Gülibik & 46 & 1.60 & Kim Korkar Kırmızı Başlıklı Kızdan & 16 & 0.56 \\
Martı & 46 & 1.60 & Kaşağı & 15 \\
Aç Tırtıl & 37 & 1.28 & Dört Kardeştiler & 0.52 \\
Pal Sokağı Çocukları & 37 & 1.28 & Sineklerin Tanrısı & 14 & 0.49 \\
Momo & 49 & 1.70 & Emile & 14 & 0.49 \\
Çıtır Çıtır Felsefe & 35 & 1.21 & Inci & 13 & 0.45 \\
Çocuk Kalbi & 32 & 1.11 & Insan Ne ile Yaşar? & 13 & 0.45 \\
Güneşe Tırmanan Çocuk & 28 & 0.97 & Üç Kedi Bir Dilek & 13 & 0.45 \\
Bilyeler & 27 & 0.94 & Cömert Ağaç & 13 & 0.45 \\
Kırmızı Fili Gördünüz mü? & 26 & 0.90 & Frederick & 12 & 0.42 \\
Martıya Uçmayı Öğreten Kedi & 26 & 0.90 & Kim Takar Salatalık Kralı & 12 & 0.42 \\
Küçük Mor Balık & 24 & 0.83 & Mış Gibi & 12 & 0.42 \\
Heidi & 23 & 0.80 & Benim Küçük Kırmızı Balığım & 12 & 0.42 \\
Bir Öykü Yazalım mı? & 22 & 0.76 & Farklı Ama Aynı & 11 & 0.38 \\
Bunun Adı Findel & 22 & 0.76 & Kedi Adası & 11 \\
Lollipop & 22 & 0.76 & Uçan Sınıf & 0.38 \\
\hline Toplam: 1588 & & & & 11 & 0.38 \\
& & & & 11 & 0.38 \\
\hline
\end{tabular}

Öğretmen adaylarının nitelikli buldukları kitaplar arasında Küçük Prens, Şeker Portakalı, Vanilya Kokulu Mektuplar, Küçük Karabalık, Uyurgezer Fil, Fadiş ve Gülibik yer almaktadır. Öte yandan öğretmen adaylarından bazılarının nitelikli çocuk edebiyatı yapıtı olarak Kuyucaklı Yusuf, Kürk Mantolu Madonna, Emile gibi yetişkinlere yönelik seslenen yapıtları yazması dersin içeriğine dönük bazı sorunların varlı̆̆ını göstermektedir.

Öğretmen adaylarının yaklaşık yarısının (\%51) nitelikli bulduğu üç kitap adını anımsaması ve yazması, çocuk edebiyatı dersinin amaçlarından olan öğretmen adaylarının nitelikli çocuk kitaplarını tanıması bağlamında olumlu bir sonuç olarak değerlendirilebilir. Buna karşın derse ilişkin bir başka sorunun varlığını çalışmaya katılan öğretmen adaylarının yarısına yakınının çocuklara seslenen nitelikli herhangi bir kitap adı anımsayamamaları göstermektedir.

\footnotetext{
${ }^{1}$ Yanlış ya da eksik yazım nedeniyle kimliği açıkça anlaşılamayan kitaplar sayıma katılmamıştır.
} 


\section{Öğretmen Adaylarının Dersin Ölçme ve Değerlendirmesi Bağlamında Görüşleri Nelerdir?}

Öğretmen adaylarının yaklaşık \%60'ı çocuk edebiyatı dersinde değerlendirme sürecinin nasıl işlediğini tam olarak bilmemektedir. Örneğin öğretmen adayları, yaptıkları sunumların ve ödevlerin geçme notuna katkısını bilmemektedir. Bu bağlamda, öğretmen adaylarının beklentileri; geçme notu ve sunumun geçme notuna katkısı vb. konulardaki belirsizliğin giderilmesi yönündedir. Kıymaz (2012)'ın çalışmasına göre öğretmen adayları uygulamanın ölçme ve değerlendirmede önemli bir yer tutmasını beklemektedirler. Kıymaz (2012)'ın çalışmasının sonuçlarıyla bu çalışmanın bulguları birbirini desteklemektedir.

Bir bütün olarak verilere bakıldığında okul öncesi öğretmenliği, sınıf öğretmenliği ve Türkçe öğretmenliği programlarından elde edilen bulgular genel olarak benzerlik göstermektedir. Buna karşın bazı konularda programlar bağlamında anlamlı farklılıklar vardır. Örneğin, "İncelediğim kitapları derste sunmam için olanak yaratıldığını düşünüyorum." maddesine okul öncesi öğretmenliği \%54.1; sınıf öğretmenliği \%47,7; Türkçe öğretmenliği \%47,6 oranında olumsuz yanıt vermiştir. Bir başka örnek ise dersin içeriğine ilişkin bölümlere göre farklılaşan görüşleri ortaya koymaktadır: "Yazınsal metin türlerine yeterince yer verildiğini düşünüyorum." Maddesine okul öncesi öğretmenliği \%61.4; sınıf öğretmenliği \%59.4; Türkçe öğretmenliği \%52 oranında olumlu yanıt vermiştir. Bu çalışmada elde edilen sonuçlar, üç lisans programında da özellikle, içerik ve eğitim durumu bağlamında sorunların olduğunu somutlamaktadır. Çalışmadan elde edilen bulgular da öğretmen adaylarının beklentileri açıkça görülmektedir. Bir bütün olarak beklentiler değerlendirildiğinde sorunlarda olduğu gibi öğretmen adaylarının beklentilerinin de özellikle içerik ve eğitim durumu başlıklarında yoğunlaştığı anlaşılmaktadır.

Sonuç olarak öğretmen adayları, çocuk edebiyatı dersinin içeriğinin zenginleştirilmesi, amaçların dersin okutulduğu programa göre yeniden düzenlemesi, derste öğrencinin daha etkin olmasına olanak tanınması, dersin süresinin arttırıması ve ölçme/değerlendirmede şeffaflık beklemektedir. Bu bağlamda çalışmanın sonuçlarına dayanarak çocuk edebiyatı dersinin geliştirilmesine ilişkin şu öneriler getirebilir:

-Çocuk edebiyatı dersi, amaçlar, içerik eğitim durumları ve ölçme/değerlendirme bağlamında öğrenci görüşleri de dikkate alınarak geliş̧irilmeli,

-Çocuk edebiyatı dersinin içeriğinin daha çok telif ve çeviri çocuk edebiyatı yapıtı örneği gösterecek şekilde düzenlenmeli,

-Öğretmenlik programlarının gereksinimlerine göre çocuk edebiyatı yapıtlarının eğitim durumlarından nasıl kullanılacağının uygulama örnekleriyle gösterilmeli,

-Bunların gerçekleştirilebilmesi için ders saatlerinin ilgili programın gereksinimine göre arttırılmalı,

-Ölçme/değerlendirme bağlamında birçok ölçme aracının birlikte kullanılmalıdır (yazılı sınavlar, sunumlar vb.).

\section{Kaynaklar}

Aslan, C. (2006). Yazınsal Nitelikli Çocuk Kitaplarının Çocuğun Okuduğunu Anlama ve Yazılı Anlatım Becerilerine Etkisi. Yayımlanmamış Doktora Tezi, Ankara Üniversitesi Sosyal Bilimler Enstitüsü, Ankara.

Aslan, C. (2007). Yazınsal Nitelikli Çocuk Kitaplarının Çocuğun Gelişim Sürecindeki Yeri. S. Sever (Ed.),

2. Ulusal Çocuk ve Gençlik Edebiyatı Sempozyumu Bildiri Kitabı (ss. 189-200). Ankara: Ankara Üniversitesi Eğitim Bilimleri Fakültesi.

Baş, B. (2015). Türkçe Öğretimi Açısında Çocuk Edebiyatı. Ankara: Pegem.

Backer, B. (2003). The weekly curriculum- 52 complete preschool themes. Beltsville MD: Gryphon House.

Büyükkavas Kuran, Ş. Ve Ersözlü, Z. N. (2009). Sınıf Öğretmenlerinin Çocuk Edebiyatına İlişkin Görüşleri. Yüzüncü Yıl Üniversitesi Eğitim Fakültesi Dergisi, VI(I), 1-17.

Campbell, S. C. (2014). Mysterious patterns: finding fractals in nature. Pennsylvania: Honesdale. 
Celepoğlu, A. ve Çetindağ, Z. (2012). Çocuk Edebiyatı Öğretimi Üzerine Bir Çalışma. VII. Uluslararası Büyük Türk Dili Kurultayı Bildirileri. Ankara: Bilkent Üniversitesi Yayınları, 284-292.

Creswell, J. W., Plano Clark V. L. (2015). Karma Yöntem Araştırmaları-Tasarımı ve Yürütülmesi (Çev. Ankara: Anı.

Çıkla, S. (2015). Tanzimattan Günümüze Çocuk Edebiyatı ve Bazı Öneriler. Hece Dergisi Çocuk Edebiyatı Özel Sayısı,104 (105), 89-107.

Demirel, Ö. (2017). Eğitimde Program Geliştirme. Ankara: Pegem.

Demircan, C. (2007). Köy Enstitüleri Eğitim-Öğretim Programlarında Çocuk Edebiyatı. Dicle Üniversitesi Ziya Gökalp Eğitim Fakültesi Dergisi, 8, 17-26.

Dilidüzgün, S. (2004). Iletişim Odaklı Türkçe Derslerinde Çocuk Kitapları. İstanbul: Morpa Kültür Yayınları.

Dilidüzgün, S. (2004a). Çağdaş Çocuk Yazını-Yazın Eğitimine Atılan İlk Adım. İstanbul: Morpa Kültür Yayınları.

Erişek, Ö., Yücel, F. (2002). Dil Öğretiminde Yazınsal Metinlerin Yeri. Osmangazi Üniversitesi Sosyal Bilimler Dergisi, 3(2), 63-76.

Güneş, F. (2013). Türkçe Öğretiminde Metin Seçimi. Ana Dili Eğitimi Dergisi, 1(1), 1-12.

Gürkan, T. (2000). Programın Yapısal Boyutları ve Program Geliştirme. Öğretimde Planlama ve Değerlendirme. Eskişehir: Anadolu Üniversitesi Açık Öğretim Yayınları.

İnce Samur, A. Ö. (2018). Öğretmen Adaylarının ve Öğretmenlerin Çocuk Edebiyatına İlişkin Görüşleri. Karaelmas Eğitim Bilimleri Dergisi, 6(2), 231-243.

Kan, O. (2011). Türkçe Öğretmenlerinin Çocuk Edebiyatı ile İlgili Görüşleri Üzerine Nitel Bir Araştırma. Ed. S. Sever, 3. Ulusal Çocuk ve Gençlik Edebiyatı Sempozyumu Bildiri Kitabı (ss.109- 118). Ankara: Ankara Üniversitesi.

Kantemir, E. (1979). Yazılı ve Sözlü Anlatım. Ankara: Ankara Üniversitesi Yayınları.

Kıymaz, M. S. (2012). Okul Öncesi Öğretmen Adaylarının Çocuk Edebiyatı Dersine İlişkin Beklentileri (Adıyaman Illi Örneği). Uşak Üniversitesi Sosyal Bilimler Dergisi, 5(3), 69-81.

Kolaç, E., Demir, T. ve Karadağ, R. (2012). Öğretmen Adaylarının Dil Eğitiminde Çocuk Edebiyatı Metinlerinin Kullanımına Yönelik Görüşleri. Türkiye Sosyal Araştırmalar Dergisi, 161, 195-213.

Kudat, C. (1996). Yabancı Dil Öğretiminde Yazınsal Metinleri Kullanımı. Dil Dergisi, 43, 32-42.

Kurdayıoğlu, M. ve Çelik, G. (2013). Türkçe Öğretmeni Adaylarının Okumaya ve Okuma Eğitimine İlişkin Özyeterlik Algıları. Uşak Üniversitesi Sosyal Bilimler Dergisi, 6(4), 109-138.

Lincoln, Y. S. ve Guba, E. G. (2013). The constructivist credo. California: Left Coast Press.

Milli Eğitim Bakanlığı. (1947). Köy Enstitüleri Öğretim Programı. Ankara: Milli Eğitim Basımevi.

Merriam, S. B. (2009). Qualitative Research: A guide to design and implementation. Jossey-Bass: San Francisco.

Nas, R. (2014). Örneklerle Çocuk Edebiyatı. Bursa: Ezgi Yayınevi.

Neydim, N. (2006). Çeviri Çocuk Edebiyatı. İstanbul: Bu Yayınevi.

Rief, S. F., Heimburge, J. A. (2006). How to reach and teach all children in the inclusive classroom: practical strategies, lessons, and activities. Jossey-Bass.

Rudman, M. K. (1995). Children's literature: an issues approach. New York: Longman.

Shavit, Z. (1986). Poetics of children's literature. Athens and London: University of Georgia Press.

Sever, S. (2007). Türkçe Öğretiminde Sanatsal Bir Uyaran Olarak Karikatürün Kullanılması. Anadolu Üniversitesi Eğitim Fakültesi VI. Ulusal Sınıf Öğretmenliği Sempozyumu Bildiri Kitabı. (ss.222229) Ankara: Nobel Yayın Dağıtım.

Sever, S. (2010). Çocuk ve Edebiyat. İzmir: Tudem.

Sever, S. (2011). Türkçe Öğretimi ve Tam Öğrenme. Ankara: Anı Yayıncılık.

Sever, S. (2013). Çocuk Edebiyatı ve Okuma Kültürü. İzmir: Tudem.

Sever, S., Kaya, Z. ve Aslan, C. (2006). Etkinliklerle Türkçe Öğretimi. İzmir: Tudem.

Şirin, M. R. (2000). 99 Soruda Çocuk Edebiyatı. Ankara: Kök Yayıncılık.

Uçgun, D. (2010). Sınıf Öğretmeni Adaylarının Çocuk Edebiyatı Dersi ve Çocuk Edebiyatı Ürünlerine Illişkin Tutumları. 9. Ulusal Sınıf Öğretmenliği Sempozyumu (ss. 472-477). Elazığ: Fırat Üniversitesi. 
Wartenberg, T. E. (2009). Teaching philosophy through children's literature. Maryland: The Rowman\&Littlefield.

Yalçın, A. ve Aytaş, G. (2016). Çocuk Edebiyatı. Ankara: Akçağ Yayınları.

Yazıcı Okuyan, H. (2009). Türkçe ve Sınıf Öğretmenlerinin Okuma Saatlerinde Kullanılan Çocuk Edebiyatı Ürünlerini Seçme Ölçütleri. Mehmet Akif Ersoy Üniversitesi Eğitim Fakültesi Dergisi, 9(18), 135-159.

Yılmaz, O. (2016). Türkçe Öğretmeni Adaylarının Çocuk Edebiyatı Dersine Illişkin Düşünceleri Üzerine Olgubilimsel Bir Araştırma. Sakarya Üniversitesi Eğitim Fakültesi Dergisi, (31), 33-59.

Yüksek Öğretim Kurulu (2007). Eğitim Fakültesi Öğretmen Yetiştirme Lisans Programları. Ankara: YÖK. Yüksek Öğretim Kurulu (2018). Eğitim Fakültesi Öğretmen Yetiştirme Lisans Programları. https://www.yok.gov.tr/kurumsal/idari-birimler/egitim-ogretim-dairesi/yeni-ogretmenyetistirme-lisans-programlari (25.12.2019 tarihinde erişildi).

\section{Extended Abstract}

\section{Introduction}

Children's literature works are not just material for the preservices teachers, but also an important part of their professional development. Concordantly, the course with which the preservices teachers would get acquaintance with quality children books is the course on "children's literature". On the other hand, children's literature course has also a important position due to its artistic content. It is also a course contributing to the overall cultural background of the preservices teachers. Having been taught in the curriculum of preschool teaching, primary school teaching, and Turkish teaching, how this course in taught at the faculties of education in Turkey should be evaluated through the opinions of the preservices teachers. Accordingly, status of children's literature course and expectations of the preservices teachers are evaluatead based on four variables of the curriculum in accordance with the opinions of the preservices teachers

\section{Method}

In this study, the "basic qualitative research design" was preferred for examining the problem of the research more profoundly. Study sample group of this study is composed of the preservices teachers $(n=1431)$ volunteered for participating to the research, having taken children literature course in the curriculum of the faculties of education, preschool teaching, primary school teaching, and Turkish teaching in Turkey. The study group was determined by the "maximum diversity" sampling methodology. This study group was composed in consideration of such variables as universities and departments in different geographic regions in order for determining the status of children's literature education at the faculties of education. To begin with, the "Questionnaire for determining opinions of the preservices teachers on children's literature course" was drawn up for the preservices teachers taking the "children's literature" course for a due diligence and analysis of requirements. In the process of preparing questionnaire, firstly, a material pool was formed in line with the literature review, and afterwards, a draft questionnaire was drawn up. This draft was formed in line with the opinions of a team of eight experts in the fields of Turkish teaching (4), curriculum and education (2), assessment and evaluation (2). As a pilot study, the questionnaire was applied to candidate teachers not included in the study group; accordingly, having revised any items not functioning properly, the questionnaire was rendered for application. The data collected in the academic year of 2015-2016, Spring Semester.

\section{Result and Discussion}

Children literature course taught at the faculties of education in Turkey was studied in the context of four variables of the curriculum based on the opinions of the preservices teachers. It is found out that according to the opinions of the preservices teachers, there are notable problems in terms of children's literature course, which contributes to professional development of the preservices teachers in many aspects as utilization of quality material by the preservices teachers being a major skill, up to the creation a multidimensional learning environment. Such problems are valid for four elements of the curriculum (aims, content, learning experineces, and evaluation). Nonetheless, the most important 
problems are in course content and learning experineces. Particularly, and some literary works for adults given as an example for kids books examples are construed as "confusion" by the preservices teachers. On the other hand, children's literature course does not support only professional development of the preservices teachers, but also provides substantial contributions to general knowledge for personal development thereof. Literature (written whether for children or adults) deeply influences those coming across with it by its very nature since it is a artistic production. Based on the opinions of the preservices teachers, Mostly, children's literature course is much more far away from such influence. Yet, the preservices teachers are expected to understand the impact an artistic work may have on human being in children's literature course. This may be accomplished only inclusion of texts of artistic children's literature in the course content. Accordingly, it is necessary to increase the course hours. 